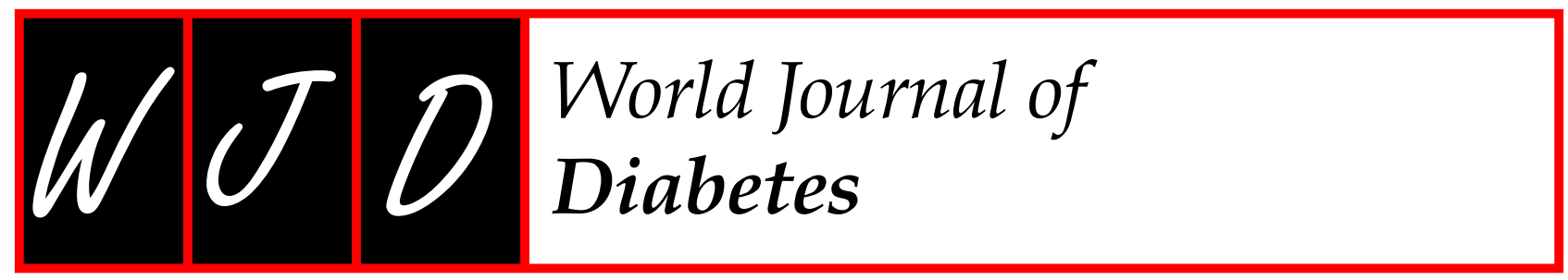

Online Submissions: http:/ / www.wjgnet.com/esps/ bpgoffice@wjgnet.com

World J Diabetes 2013 December 15; 4(6): 270-281

doi:10.4239/wjd.v4.i6.270

ISSN 1948-9358 (online)

(C) 2013 Baishideng Publishing Group Co., Limited. All rights reserved.

TOPIC HIGHLIGHT

WJD $5^{\text {th }}$ Anniversary Special Issues (2): Type 2 diabetes

\title{
Type 2 diabetes mellitus in children and adolescents
}

\author{
Thomas Reinehr
}

Thomas Reinehr, Vestische Kinder- und Jugendklinik, University of Witten- Herdecke, 45711 Datteln, Germany

Author contributions: Reinehr T solely contributed to this work.

Correspondence to: Thomas Reinehr, Professor, Vestische Kinder- und Jugendklinik, University of Witten- Herdecke, Dr. F. Steiner Str. 5, 45711 Datteln,

Germany. t.reinehr@kinderklinik-datteln.de

Telephone: +49-2363-975229 Fax: +49-2363-975218

Received: September 12, 2013 Revised: November 5, 2013

Accepted: November 20, 2013

Published online: December 15, 2013

\section{Abstract}

Type 2 diabetes mellitus is emerging as a new clinical problem within pediatric practice. Recent reports indicate an increasing prevalence of type 2 diabetes mellitus in children and adolescents around the world in all ethnicities, even if the prevalence of obesity is not increasing any more. The majority of young people diagnosed with type 2 diabetes mellitus was found in specific ethnic subgroups such as African-American, Hispanic, Asian/Pacific Islanders and American Indians. Clinicians should be aware of the frequent mild or asymptomatic manifestation of type 2 diabetes mellitus in childhood. Therefore, a screening seems meaningful especially in high risk groups such as children and adolescents with obesity, relatives with type 2 diabetes mellitus, and clinical features of insulin resistance (hypertension, dyslipidemia, polycystic ovarian syndrome, or acanthosis nigricans). Treatment of choice is lifestyle intervention followed by pharmacological treatment (e.g., metformin). New drugs such as dipeptidyl peptidase inhibitors or glucagon like peptide 1 mimetics are in the pipeline for treatment of youth with type 2 diabetes mellitus. However, recent reports indicate a high dropout of the medical care system of adolescents with type 2 diabetes mellitus suggesting that management of children and adolescents with type 2 diabetes mellitus requires some remodeling of cur- rent healthcare practices.

(c) 2013 Baishideng Publishing Group Co., Limited. All rights reserved.

Key words: Type 2 diabetes mellitus; Children; Clinical manifestation; Screening; Comorbidity; Treatment

Core tip: Review of the current stage of diagnosis and treatment of type 2 diabetes in children and adolescents.

Reinehr T. Type 2 diabetes mellitus in children and adolescents. World J Diabetes 2013; 4(6): 270-281 Available from: URL: http://www.wjgnet.com/1948-9358/full/v4/i6/270.htm DOI: http://dx.doi.org/10.4239/wjd.v4.i6.270

\section{INTRODUCTION}

Thirty years ago, type 2 diabetes mellitus has been thought to be a rare occurrence in children and adolescents. However, in the mid-1990s, investigators began to observe an increasing incidence of type 2 diabetes mellitus worldwide $^{[1]}$. This is particularly the case in the United States ${ }^{[1,2]}$ but has also been reported in other countries like Canada, Japan, Austria, United Kingdom and Germany ${ }^{[3-10]}$. In some regions in the United States, type 2 diabetes mellitus is as frequent as type 1 diabetes mellitus in adolescents ${ }^{[1]}$.

This observation followed a striking increase both the prevalence and the degree of obesity in children and adolescents in many populations ${ }^{[12,13]}$. Overweight is at present the most common health problem facing children in both develop and developing countries ${ }^{[13]}$. While obesity is not increasing any more in the United States and some countries in Europe ${ }^{[14,15]}$, the prevalence of type 2 diabetes mellitus has been increased threefold ${ }^{[15]}$. This has been attributed to the fact, that the prevalence of obesity is not increasing but the degree of obesity in affected children and adolescents ${ }^{[15]}$.

Type 2 diabetes mellitus is a serious and costly dis- 
ease. The chronic complications of diabetes mellitus include accelerated development of cardiovascular diseases, end-stage renal disease, loss of visual acuity, and limb amputations. All of these complications contribute to the excess morbidity and mortality in individuals with diabetes mellitus.

Since the incidence and prevalence of type 2 diabetes mellitus in children are increasing and if this increase cannot be reversed, our society will face major challenges. That is, the burden of diabetes mellitus and its complications will affect many more individuals than currently anticipated, and the cost of diabetes mellitus to our society will cause us to consume enormous resources.

\section{PATHOPHYSIOLOGY OF TYPE 2 DIABE- TES MELLITUS IN CHILDREN AND ADO- LESCENTS}

Type 2 diabetes mellitus is a complex metabolic disorder of heterogeneous etiology with social, behavioral, and environmental risk factors unmasking the effects of genetic susceptibility ${ }^{[16]}$. There is a strong hereditary (likely multigenic) component to the disease, with the role of genetic determinants illustrated when differences in the prevalence of type 2 diabetes mellitus in various racial groups are considered ${ }^{[17]}$. Although substantial progress in our knowledge of the genetic basis of type 2 diabetes mellitus is taking place, these new discoveries represent but a small proportion of the genetic variation underlying the susceptibility to this disorder ${ }^{[17]}$. Furthermore, the recent increases observed in diabetes mellitus prevalence are too quickly to be the result of increased gene frequency and altered gene pool, emphasizing the importance of environmental factors.

Glucose homeostasis depends on the balance between insulin secretion by the pancreatic $\beta$-cells and insulin action. It is well recognized that insulin resistance to insulin-stimulated glucose uptake is a characteristic finding in patients with type 2 diabetes mellitus and impaired glucose metabolism. The evolution from normal to impaired glucose tolerance (IGT) is associated with a worsening of insulin resistance. Impaired glucose tolerance is an intermediate stage in the natural history of type 2 diabetes mellitus and is a predictor of the risk of developing diabetes mellitus and cardiovascular disease $\mathrm{e}^{[7,10,11,18]}$. However, there is a high spontaneous conversion rate from IGT to normal glucose tolerance in the next 3 to 5 years in children and adolescents with impaired glucose tolerance ${ }^{[19,20]}$. This normalization has been attributed to changes of insulin resistance at end of puberty.

Puberty appears to play a major role in the development of type 2 diabetes mellitus in children ${ }^{[11]}$. During puberty, there is increased resistance to the action of insulin, resulting in hyperinsulinemia. After puberty, basal and stimulated insulin responses decline. Hyperinsulinemic- euglycemic clamp studies demonstrated that insulin-mediated glucose disposal is on average $30 \%$ lower in adolescents between Tanner stage II and IV compared with prepubertal children and with young adults. Increased growth hormone secretion in puberty is discussed to be responsible for the insulin resistance during puberty ${ }^{[21]}$. Given this information, it is not surprising that the peak age at presentation of type 2 diabetes mellitus in children coincides with the usual age of mid-puberty ${ }^{[3,11]}$.

For diabetes mellitus to develop insulin resistance alone is not sufficient and inadequate $\beta$-cell insulin secretion is necessary ${ }^{[7,10,11,18]}$. In patients with type 2 diabetes mellitus, impaired insulin action and insulin secretory failure are both present. It has been proposed that hyperglycemia may worsen both insulin resistance and insulin secretory abnormalities, thus enhancing the transition from impaired glucose tolerance to diabetes mellitus ${ }^{[1]}$.

The adverse effect of obesity on glucose metabolism is evident early in childhood. Obese children are hyperinsulinemic and have approximately 40\% lower insulinstimulated glucose metabolism compared with nonobese children $^{[22]}$. Furthermore, the inverse relationship between insulin sensitivity and abdominal fat is stronger for visceral than for subcutaneous fat ${ }^{[22,23]}$.

It is interesting to note that adipose tissue expanding in the obese state synthesizes and secretes metabolites and signaling proteins like leptin, adiponectin, and tumor necrosis factor-alpha. These factors are known to alter insulin secretion and sensitivity and even cause insulin resistance under experimental and clinical conditions ${ }^{[24]}$.

Racial differences in insulin sensitivity are also evident in childhood. African-American 7- to 11-year-old children have significantly higher insulin levels than agematched white children ${ }^{[25]}$. These data suggest that particular ethnic groups may have a genetic predisposition to insulin resistance, which may increase their risk for type 2 diabetes mellitus. In concordance, obese Swedish children have higher fasting glucose levels than obese German children ${ }^{[26]}$.

\section{EPIDEMIOLOGY OF TYPE 2 DIABETES MELLITUS IN CHILDREN AND ADOLES- CENTS}

The prevalence of type 2 diabetes mellitus in children and adolescents in the United States is approximately $12: 100000^{[15,27,28]}$, while it is still rare in Europe (approximately $2.5: 100000)^{[8,29]}$. The majority of young people diagnosed with type 2 diabetes mellitus was found in specific ethnic subgroups such as African-American, Hispanic, Asian/Pacific Islanders and American Indians being highest in Pima Indians (22.3/1000 in 10 14-year-old children ${ }^{[30]}$. Furthermore, the great majority of the children were obese. Screening studies in obese adolescents have reported a prevalence of $0.4 \%$ up to $1 \%$ of type 2 diabetes mellitus in obese children $\geqslant 12$ years ${ }^{[3,31,32]}$. Within the whole pediatric cohort surveyed, 
Table 1 Comparison between Caucasian and non-Caucasian children and adolescents with type 2 diabetes mellitus

\begin{tabular}{lcc}
\hline & Caucasian & Non-Caucasian \\
\hline Mean age at onset in years & 14 & 12 \\
Gender & Female $>$ male & Female $>$ male \\
Clinical manifestation & $50 \%$ asymptomatic & $33 \%$ asymptomatic \\
& $4 \%$ ketoacidosis & $5 \%-25 \%$ ketoacidosis \\
Obese & $90 \%$ & $90 \%$ \\
Acanthosis nigricans & $50 \%$ & $90 \%$ \\
$1^{\text {st }}$ - and $2^{\text {nd }}$ - degree relatives & $83 \%$ & $74 \%-100 \%$ \\
with type 2 diabetes mellitus & & \\
mellitus & & \\
\hline
\end{tabular}

Table adapted from Reference [3].

the overall incidence of type 2 diabetes mellitus remained low when compared with type 1 diabetes mellitus. This had led some researchers to question the claims of an "epidemic" of pediatric type 2 diabetes mellitus ${ }^{[33]}$, although there is general agreement that type 2 diabetes mellitus in youth appears to be emerging as a serious clinical issue ${ }^{[9,34]}$.

\section{CLINICAL PRESENTATION OF TYPE 2 DIABETES MELLITUS IN CHILDREN AND ADOLESCENTS}

Obesity is the hallmark of type 2 diabetes mellitus ${ }^{[10]}$. Most children with type 2 diabetes mellitus are obese or extremely obese at diagnosis and present with glucosuria without ketonuria, absent or mild polyuria and polydipsia, and little or no weight loss ${ }^{[3,10]}$. Currently, children with type 2 diabetes mellitus are usually diagnosed over the age of 10 years and are in middle to late puberty ${ }^{[3,10,11]}$.

In the type 2 diabetes mellitus mildest form, the diagnosis is made in an asymptomatic child during a routine medical check-up by detection of hyperglycaemia or glycosuria ${ }^{[10]}$. One third of patients are diagnosed by urinanalysis during routine physical examination ${ }^{[10,11]}$. In its severest form, the child presents with polyuria, polydipsia, and weight loss. Up to $33 \%$ in particular ethnic groups have ketonuria at diagnosis and 5\%-25\% ketoacidosis at presentation ${ }^{[10,11]}$ (Table 1). Vary rare, type 2 diabetes mellitus manifest with a hyperglycaemic hyperosmolare coma. With these clinical pictures, often the distinction from type 1 diabetes mellitus is not possible until months later, when insulin requirements decline and a non-insulin-dependent course develops without dependence on insulin for survival.

Children with type 2 diabetes mellitus frequently have a family history of type 2 diabetes mellitus and those of non-European ancestry (Americans of African, Hispanic, Asian, and American Indian descent) are disproportionately represented. Of the patients, $74 \%-100 \%$ have a first- or second-degree relative with type 2 diabetes mellitus ${ }^{[10]}$. Of note, diabetes mellitus in parents or other relatives may not be recognized until the child is diagnosed.
Acanthosis nigricans and polycystic ovarian syndrome (PCOS), disorders associated with insulin resistance and obesity, are common in youth with type 2 diabetes mellitus ${ }^{[10]}$. Acanthosis is a cutaneous finding characterised by velvety hyperpigmented patches most prominent in intertrigenous area. It is present in up to 50 up to $90 \%$ of children with type 2 diabetes mellitus. It is recognised more frequently in darker-skinned obese individuals. PCOS is characterised by hyperandrogenism and chronic anovulation. Lipid disorders and hypertension also occur more frequently in children with type 2 diabetes mellitus.

Most of the Caucasian children and adolescents with type 2 diabetes mellitus were asymptomatically at diagnosis in contrast to other ethnicities (Table 1). The minority populations demonstrated at manifestation of diabetes mellitus frequently more symptoms and higher insulin and C-peptide levels ${ }^{[11]}$.

Some syndromes such as Klinefelter syndrome, Bardet Biedl Syndrome, Prader Willi Syndrome and Alström Syndrom are associated with type 2 diabetes mellitus. They all are associated with mental retardation and frequently to extreme obesity.

\section{DIFFERENTIAL DIAGNOSIS OF TYPE 2 DIABETES MELLITUS IN CHILDREN AND ADOLESCENTS}

Individuals with type 2 diabetes mellitus may have clinical presentations indistinguishable from those of patients with other types of diabetes mellitus ${ }^{[10]}$. This is relevant because as the number of children with type 2 diabetes mellitus increases, it becomes increasingly important to classify their diabetes mellitus correctly so that appropriate therapy may be instituted.

Typically, children with type 1 diabetes mellitus are not overweight and have recent weight loss, polydipsia, and polyuria (Table 2$)^{[10]}$. They have a short duration of symptoms and frequently have ketoacidosis at presentation $^{[7,10,35]}$. After metabolic stabilization, they may have an initial period of diminished insulin requirement, after which they require insulin for survival.

It should be highlighted, that none of symptoms and factors in Table 2 relate to a definite diagnosis. For example, the increased prevalence of type 2 diabetes mellitus within the whole population means that many individuals with type 1 diabetes mellitus are now more likely to have a family history of type 2 diabetes mellitus. Likewise, type 1 diabetes mellitus also presents in overweight/obese individuals and indeed the prevalence of weight-related problems in type 1 diabetes mellitus appears to be significant ${ }^{[36]}$.

Even if type 2 diabetes mellitus is defined by the absence of $\beta$-cell autoantibodies ${ }^{[7,18]}$, some studies reported of nearly $30 \% \beta$-cell autoantibodies in European children and adolescents clinically appearing as type 2 diabetes mellitus ${ }^{[4,11,37]}$. These children have a non-insulin dependent children over a period $>1$ year. The possibility that 
Table 2 Clinical characteristics of type 1, type 2 and MODY diabetes mellitus

\begin{tabular}{|c|c|c|c|}
\hline Clinical characteristic & Type 1 diabetes mellitus & Type 2 diabetes mellitus & MODY diabetes mellitus \\
\hline Age when diagnosis is established & Preschool-adolescents & $>10 \mathrm{yr}$ & $\begin{array}{l}\text { MODY 2: youth } \\
\text { MODY 3: adolescents }\end{array}$ \\
\hline Obesity & Uncommon $^{1}$ & Common & Uncommon \\
\hline Gender & Male $=$ female & Female $>$ male & Male $=$ female \\
\hline Relatives & 5\% Type 1 D.m. & 75\%-100\% Type 2 D.m. & $100 \%$ MODY \\
\hline Population & Predominantly Caucasian & $\begin{array}{l}\text { Predominantly Americans of African, } \\
\text { Hispanic, Asian, and American Indian }\end{array}$ & \\
\hline b-cell autoantibodies & $85 \%-98 \%$ & Uncommon $^{2}$ & Uncommon \\
\hline Insulin, C-peptide & Low & high & Low \\
\hline Ketoacidosis & Frequently & $<33 \%$ & Uncommon \\
\hline Associated disorders & $\begin{array}{l}\text { Autoimmune disorders (thyroid, } \\
\text { adrenal, vitiligo), celiac disease }\end{array}$ & $\begin{array}{l}\text { Acanthosis nigricans } \\
\text { PCOS } \\
\text { Metabolic Syndrome }\end{array}$ & $\begin{array}{l}\text { MODY 5: urogenital malformation } \\
\text { MODY 8: exocrine pancreas insufficency }\end{array}$ \\
\hline
\end{tabular}

${ }^{1}$ But prevalence of overweight children with type 1 diabetes mellitus is increasing parallel to the obesity epidemic; ${ }^{2} \mathrm{Children}$ with type 2 diabetes mellitus and b-cell autoantibodies have been reported. MODY: Maturity onset of diabetes mellitus in youth.

positive $\beta$-cell antibodies in these non insulin-requiring diabetic children and adolescents represent a form of early-onset latent autoimmune diabetes mellitus similar to that described in adults (LADA: latent autoimmune diabetes mellitus of the adult) needs to be considered. Worldwide studies have identified 10\%-20\% of diabetic patients with $\beta$-cell autoantibodies in non-insulinrequiring adult diabetics ${ }^{[38-40]}$. Patients with LADA share insulin resistance with type 2 diabetes mellitus patients but display a more severe defect in $\beta$-cell capacity ${ }^{[41]}$. Following the terminology "latent autoimmune diabetes mellitus in adulthood", the non-insulin dependent diabetic children and adolescents with $\beta$-cell autoantibodies could be named "latent autoimmune diabetes mellitus in youth" (LADY). Double diabetes mellitus or type 1.5 diabetes mellitus are other proposed names for this entity.

The accelerator hypothesis postulates a shared basis for both type 1 and type 2 diabetes mellitus: Besides individual predisposition and autoimmunity, insulin resistance is discussed to lead to $\beta$-cell insufficiency ${ }^{[42,43]}$. In the prediabetic period of an immune-mediated destruction of $\beta$-cells, increasing insulin resistance can result in clinical diabetes mellitus ${ }^{[38]}$. Obesity and puberty are important factors for developing insulin resistance in childhood and adolescence ${ }^{[22]}$. Apart from $\beta$-cell autoantibodies in children clinically classified as type 2 diabetes mellitus, negative autoantibodies in children with type 1 diabetes mellitus with acute-onset of diabetes mellitus, severe metabolic impairment and insulin requirement only in the early stage of disease are reported ${ }^{[7,9]}$. In conclusion, type 1 and type 2 diabetes mellitus do not seem to be completely distinctive and can overlap considerably. Therefore, serology cannot completely distinguish these two types of diabetes mellitus.

Maturity-onset of diabetes mellitus of the young (MODY) is another rare form of diabetes mellitus in children that includes several disorders caused by monogenic defects in $\beta$-cell function ${ }^{[44]}$. MODY 2 (defect in glucokinase) and MODY 3 (defect in HNF1 $\alpha$ ) are the most frequent types of MODY. Patients with MODY have a dominant genetic trait, usually are non-obese and have low fasting insulin levels. Recent studies suggest that the clinical presentation of MODY is broad, ranging from asymptomatic hyperglycemia to a severe acute presentation. MODY has been reported in all races/ethnicities. These gene abnormalities are thought to be rare, and molecular diagnostic testing.

\section{DIAGNOSTIC CRITERIA OF TYPE 2 DIA- BETES MELLITUS IN CHILDREN AND ADOLESCENTS}

The criteria for diagnosis of diabetes mellitus in children and adolescents are symptoms of diabetes mellitus such as polydipsia, polyuria, and unexplained weight loss plus casual glucose concentration $\geqslant 200 \mathrm{mg} / \mathrm{dL}(11.1 \mathrm{mmol} / \mathrm{L})$ in venous plasma, fasting glucose $\geqslant 126 \mathrm{mg} / \mathrm{dL}(7.0 \mathrm{mmol} / \mathrm{L})$ in venous or capillary plasma, or two-hours glucose during oGTT $\geqslant 200 \mathrm{mg} / \mathrm{dL}(11.1 \mathrm{mmol} / \mathrm{L})$ in venous plasma or capillary whole blood sample. Recently revised American Diabetes mellitus Association (ADA) criteria allow utilization of hemoglobin A1c (HbA1c) $\geqslant 6.5 \%$ for diagnosis of diabetes mellitus ${ }^{[18,45]}$. In case of asymptomatic manifestation, fasting glucose, HbA1c, or oGT'T test has to be repeated on another day for diagnosis ${ }^{[7,10,18]}$.

In most patients with diabetes mellitus, classification can be made reliably on the basis of clinical presentation and course $\mathrm{e}^{[7,10,18]}$. In the unusual circumstance that requires a specific classification to be made, other test may be necessary, such as fasting insulin or C-peptide determination and occasionally, $\beta$-cell autoantibodies measurements (Figure 1). To achieve a high degree of sensitivity, a combination of test is required, which greatly increases the cost of classification.

C-peptide levels are elevated in individuals with type 2 diabetes mellitus in contrast to patients with type 1 diabetes mellitus or MODY diabetes. Specific autoantibodies to insulin, to GAD- II, or to tyrosine phosphatases insulin antibodies (IA)-2 and IA-2b are found at presentation in $85 \%-98 \%$ of individuals with immunemediated type 1 diabetes mellitus ${ }^{[7,35]}$. Type 1 diabetes 
Table 3 Criteria for testing of type 2 diabetes mellitus in children and adolescents

Overweight (BMI > 90 percentile) plus one of the following risk factors: Family history of type 2 diabetes mellitus in first- or second-degree relative

Race/ethnicity (Asian, American Indian, Africa-Americans, Hispanics) Signs of insulin resistance or conditions associated with insulin resistance (acanthosis nigricans, hypertension, dyslipidemia, polycystic ovarian syndrome)

Extreme obesity (BMI > 99.5 percentile)

Table adapted from Reference [7]. BMI: Body mass index.

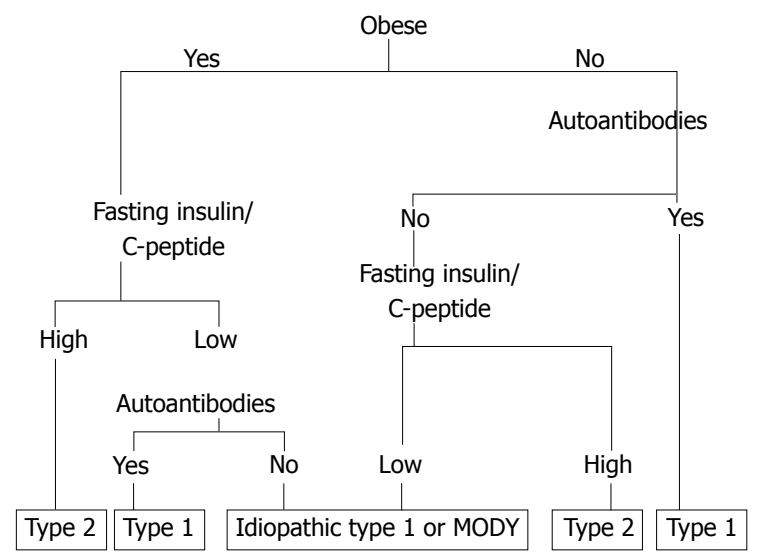

Figure 1 Flow sheet for classification of diabetes mellitus in children and adolescents. Adapted from Reference [7], cave autoantibodies also appear in type 2 diabetes mellitus. MODY: Maturity onset of diabetes mellitus in youth.

mellitus also has a strong HLA association; however, HLA typing is not a useful diagnostic tool.

\section{SCREENING FOR TYPE 2 DIABETES MEL- LITUS IN CHILDREN AND ADOLESCENTS}

Most of the European Caucasian children and adolescents with type 2 diabetes mellitus and one third of the American children were asymptomatically at diagnosis. According to this, the prevalence in screening studies in Europe of obese children was much higher than the prevalence rate reported in the standardised documentation system of diabetes mellitus for example in Germany $^{[3246]}$. Therefore it is likely that, as with adults, undiagnosed type 2 diabetes mellitus is a common condition in childhood $^{[47]}$. In conclusion, a screening of type 2 diabetes mellitus seems necessary since unrecognised hyperglycaemia would undoubtedly contribute to both microvascular and macrovascular risk in later life ${ }^{[11]}$.

However, at the present time, a general screening for type 2 diabetes mellitus in youth is unlikely to be costeffective. Therefore a targeted screening seems to be necessary. Consistent with the recommendations for screening in adults, only children at substantial risk for the presence or the development of type 2 diabetes mellitus should be tested. Screening in high- risk population demonstrated type 2 diabetes mellitus in approximately
$1 \%$ of obese Caucasian children in Germany ${ }^{[32,46]}$ and in $4 \%$ of screened obese adolescents in particular ethnic groups in the United States ${ }^{[31]}$. The ADA recommends a screening in overweight children and adolescents at onset of puberty in high risk patients (Table 3$)^{[7]}$. Testing should be performed every 2 years starting at the age of 10 years or at onset of puberty if it occurs in a younger age by fasting glucose or oGTT ${ }^{[7]}$.

However, these screening recommendations have some pitfalls. Requirements for testing an asymptomatic group include the availability of a test that is sensitive (few false negatives) and accurate with acceptable specificity (minimal number of false positive). Since fasting blood glucose failed to diagnose diabetes mellitus in one fourth of children with type 2 diabetes mellitus in the European cohort $^{[3]}$, oGT'T seems to be a better screening tool even if fasting glucose is preferred because of its lower costs and greater convenience. However, the low reproducibility of an oGT'T has to be kept in mind ${ }^{[48]}$. Using the criteria (1) type 2 diabetes mellitus in the first or second degree relatives, (2) onset of puberty, and (3) extreme obesity allows to identify the great majority of overweight European children, which should be screened by oGTT, when two of this three criteria are fulfilled ${ }^{[49]}$. Studies using HbA1c as screening tool were disappointing, since one third of the asymptomatic children with type 2 diabetes mellitus demonstrated normal values ${ }^{[3]}$. The standardisation process of the HbA1c may have improved its screening value, since $\mathrm{HbA} 1 \mathrm{c}$ has been included in the ADA recommendation for the diagnosis of diabetes mellitus ${ }^{[18,45]}$. However, studies testing the usefulness of $\mathrm{HbA} 1 \mathrm{c}$ after the standardisation process as screening tool are missing yet.

\section{COMPLICATIONS OF TYPE 2 DIABETES MELLITUS IN CHILDREN AND ADOLES- CENTS}

The chronic complications of diabetes mellitus in adults include macrovascular disease like accelerated development of cardiovascular disease leading to stroke and myocardial infarction, and microvascular diseases like retinopathy, nephropathy and neuropathy leading to end-stage renal disease, loss of visual acuity, and limb amputations. All of these complications contribute to the excess morbidity and mortality in individuals with diabetes mellitus. One notable outcome of the UK Prospective Diabetes mellitus Study (UKPDS) analysis was the observation that the accrual of endpoints was a time dependent process ${ }^{[50]}$. Therefore, children and adolescents with type 2 diabetes mellitus have a higher risk for complication as compared to adults with diabetes mellitus. Accordingly, developing type 2 diabetes mellitus at a younger age is also associated with a much higher risk of long-term cardiovascular disease than those who develop type 2 diabetes mellitus in middle age ${ }^{[51]}$. Young people with type 2 diabetes mellitus appear to be at a much higher risk of developing early diabetes mellitus 
associated complications than those with type 1 diabetes mellitus. This higher level of risk does not appear to be related to overall levels of glycemic control or duration of disease but to occurrence of hypertension and dyslipidemia ${ }^{[52]}$. These cardiovascular risk factors are more frequent in adolescents suffering from type 2 diabetes mellitus compared to type 1 diabetes mellitus ${ }^{[35]}$. In the TODAY study, $14 \%$ of adolescents with type 2 diabetes mellitus suffered from hypertension, $80 \%$ demonstrated low HDL concentrations, and 10\% had hypertriglyceridemia $^{[35]}$. In the SEARCH study, $92 \%$ of the adolescents with type 2 diabetes mellitus fulfilled the definition of metabolic syndrome ${ }^{[2]}$. These prevalences are similar to cardiovascular risk factors in European adolescents with type 2 diabetes mellitus ${ }^{[4,53]}$.

We know little about the onset and progress of macrovascular disease in children and adolescents with type 2 diabetes mellitus. Arteriosclerosis is a time dependent phenomenon, and thus the absolute time from diagnosis to developing pathological cardiovascular lesions may be many years - in that sense these children may be protected by age since they do not have pre-existing age related cardiovascular disease. However, already adolescents with type 2 diabetes mellitus demonstrated an increased intima-media thickness ${ }^{[54]}$, which is predictive for heart attack and stroke ${ }^{[55]}$.

Microvascular disease is the hallmark of hyperglycaemia diagnosed at a young age. Data from Japanese, Pima Indian children show the presence of microvascular diabetic complications already at diagnosis and follow-up ${ }^{[1]}$. In Japanese children, incipient retinopathy was detected in $36 \%$ of the cases at the time of diagnosis, and in $39 \%$ of the cases at 2 years follow-up, while microalbuminuria was observed in $39 \%$ at 2 years follow-up ${ }^{[56]}$. Among Pima Indian children, $22 \%$ had microalbuminuria, and at follow-up between 20 and 29 years of age $60 \%$ had microalbuminuria and $17 \%$ had already macroalbuminuria ${ }^{[57]}$. In the SEARCH study, $4 \%$ of the adolescents with type 2 diabetes mellitus demonstrated retinopathia and $28 \%$ microalbuminuria ${ }^{[2]}$. In contrast, in European adolescents with type 2 diabetes mellitus no retinopathia and only $5 \%$ microalbuminuria was reported $^{[4,53]}$ suggesting genetic differences.

\section{TREATMENT OF TYPE 2 DIABETES MEL- LITUS IN CHILDREN AND ADOLESCENTS}

The American Academy of Pediatrics has, very recently, published management guidelines how to treat children and adolescents with type 2 diabetes mellitus ${ }^{[9]}$. The ideal goal of treatment is normalization of blood glucose values and HbA1c $\mathrm{c}^{[10]}$. Successful control of the associated comorbidities, such as hypertension and dyslipidemia, is also important ${ }^{[10]}$. The ultimate goal of treatment is to decrease the risk of acute and chronic complications associated with diabetes mellitus.

Most of the recommended guidelines for treatment in children with type 2 diabetes mellitus are extrapolated from experience gained in adults ${ }^{[7,9,10]}$. Despite of severe manifestation, initial management of obese children and adolescents with type 2 diabetes mellitus should consist of behaviour modification strategies for lifestyle change such as decreasing high-caloric high-fat food choice and sedentary behaviour, while increasing physical activity $^{[58]}$. Weight control is essential for reaching treatment goals and are effective to treat type 2 diabetes mellitus in adolescents ${ }^{[59]}$. However, lifestyle changes cannot be imposed and self-motivation is necessary ${ }^{[00,61]}$. Referral to a dietician with knowledge and experience in nutritional management of children with diabetes mellitus is necessary ${ }^{[60]}$. Dietary recommendations should be culturally appropriate, sensitive to the family resources, and provided to all caregivers. Encouraging healthy eating habits by the entire family is important ${ }^{[58,60]}$.

All children with type 2 diabetes mellitus should receive comprehensive self-management education ${ }^{[1,60]}$ : Self-management education should include teaching selfmonitoring of blood glucose (SMBG). SMBG should be performed as needed and during periods of acute illness or when symptoms of hyper- or hypoglycaemia occur. Patients on insulin should also monitor periodically for asymptomatic hypoglycaemia. Routine blood glucose monitoring should be tailored to individual needs but should probably include a combination of fasting and postprandial glucose measurements. HbA1c should be assayed to monitor glycemic control.

Since only a few of youths with type 2 diabetes mellitus can be treated with diet and exercise alone $e^{[61]}$, pharmacological intervention is frequently required to achieve normoglycemic state.

\section{PHARMACOLOGICAL TREATMENT OF TYPE 2 DIABETES MELLITUS IN CHIL- DREN AND ADOLESCENTS}

If treatment goal (HBA1c $<7 \%$ ) with nutrition education and exercise is not met, pharmacological therapy is indicated ${ }^{[0,10]}$. Many drugs are available for individuals with type 2 diabetes (Table 4), although only metformin and insulin are currently licensed for use for under 18-year-old ${ }^{[10]}$. Most paediatric diabetologists use oral agents for children with type 2 diabetes mellitus. Advantages of oral agents include potentially greater compliance and convenience for the patient. Clinical features suggesting initial treatment with insulin include dehydratation, presence of ketosis, and acidosis.

Metformin, a biguanide, is undoubtedly the most appropriate starting point for pharmacological treatment in children with type 2 diabetes mellitus. The effectiveness has been proven for adolescents in a randomized controlled trial ${ }^{[62]}$. Metformin decreases hepatic glucose output and enhances primarily hepatic and also muscle insulin sensitivity without a direct effect on $\beta$-cell function. Metformin has the advantage of weight reduction, decrease in lipids without the risk of hypoglycaemia. Because of concerns about lactic acidosis metformin is contraindicated in patients with impaired renal function 
Table 4 Treatment option of type 2 diabetes mellitus in children and adolescents [Federal Drug Administration (United States), European Medicine Evaluation Agency (European)]

\begin{tabular}{|c|c|c|c|c|c|}
\hline Modality & $\begin{array}{l}\text { Glycaemia } \\
\text { reduction }\end{array}$ & $\begin{array}{c}\text { Enhance } \\
\text { insulin secretion }\end{array}$ & $\begin{array}{l}\text { Insulin resistance } \\
\text { lowering }\end{array}$ & $\begin{array}{l}\text { FDA/EMEA approved } \\
\text { for children }\end{array}$ & Notes \\
\hline Diet and exercise & Yes & No & Yes & Yes & $\begin{array}{l}\text { First-line approach } \\
\text { Efficacy depends on successful } \\
\text { ife-style change }\end{array}$ \\
\hline Insulin & Yes & No & No & Yes & $\begin{array}{l}\text { Weight gain discussed } \\
\text { risk of hypoglycemia }\end{array}$ \\
\hline Metformin & Yes & No & Yes & Yes & $\begin{array}{l}\text { Good safety record } \\
\text { minimal weight loss }\end{array}$ \\
\hline Sulphonylureas & Yes & Yes & No & No & $\begin{array}{l}\text { Good safety record in adults } \\
\text { risk of hypoglycemia }\end{array}$ \\
\hline Meglitinide analogues & Yes & Yes & No & No & Sparse data on their use \\
\hline Thiazolidinediones & Yes & $?$ & Yes & No & $\begin{array}{l}\text { Weight gain } \\
\text { lack of long-term data }\end{array}$ \\
\hline $\begin{array}{l}\text { Dipeptidyl peptidase inhibitors (DPP4)/ } \\
\text { glucagon like peptide (GLP) } 1 \text { mimetics }\end{array}$ & Yes & No & No & No & $\begin{array}{l}\text { Moderate weight loss } \\
\text { Carcinoma of the pancreas discussed } \\
\text { Lack of long-term data }\end{array}$ \\
\hline $\begin{array}{l}\text { Sodium-Glucose Cotransporter } 2 \\
\text { Inhibitors }\end{array}$ & Yes & No & No & No & $\begin{array}{l}\text { Minimal weight loss } \\
\text { Urinary and genital tract infections } \\
\text { Risk of hypoglycaemia } \\
\text { Sparse data on their use } \\
\text { Lack of long-term data }\end{array}$ \\
\hline Acarbose & $?$ & No & No & No & Side effects may be unacceptable \\
\hline Orlistat & $?$ & No & No & No & Side effects may be unacceptable \\
\hline Surgical treatment of obesity & Yes & No & Yes & No & Some anecdotal evidence \\
\hline
\end{tabular}

?: Unknown; FDA: Federal Drug Administration; EMEA: European Medicine Evaluation Agency.

and should be discontinued with the administration of radiocontrast material or hypocaloric diet. Metformin should not be used in patients with known hypoxemic conditions, severe infection, hepatic disease, or alcohol abuse. The most common side effects of metformin are gastrointestinal disturbances. The dose of metformin should be increased up to $2 \mathrm{~g}$ in split doses, unless there are gastrointestinal side effects. Metformin has a good safety record, but should not be given if there is any doubt at all about the nature of diagnosis.

If monotherapy with metformin is not successful over a reasonable period of time (3-6 mo), several alternatives can be considered. Other drugs, which are not approved for children and adolescents, have been less frequently used in children. No oral agent should be used during pregnancy. The use of rosiglitazone has been studied in a randomized trial in adolescents compared to lifestyle intervention and metformin in the TODAY study ${ }^{[63]}$ : Monotherapy with metformin was associated with durable glycemic control in approximately half of children and adolescents with type 2 diabetes mellitus. The addition of rosiglitazone, but not an intensive lifestyle intervention, was superior to metformin alone. However, rosiglitazone has been withdrawn from the market due to its side effects and is not available any more.

Insulin treatment will often be the only feasible way of controlling hyperglycaemia. There is no specific contraindication in children. Insulin regimes should be adopted that are carefully tailored to lifestyle (bedtime insulin alone, twice-a-day insulin or multidose insulin regimes).

In those extremely obese adolescents where lifestyle change and pharmacotherapy have been unsuccessful, then bariatric surgery may need to be considered ${ }^{[64]}$.

\section{MONITORING AND TREATMENT OF COM- PLICATIONS OF TYPE 2 DIABETES MEL- LITUS IN CHILDREN AND ADOLESCENTS}

Since microvascular complications of type 2 diabetes mellitus like retinopathy and nephropathy already occur in children, dilated eye examinations should be performed ${ }^{[1,60]}$. Screening for microalbuminuria should also be performed yearly ${ }^{[1,7]}$. Angiotensin converting enzyme (ACE) inhibitors are the agents of choice in children with microalbuminuria ${ }^{[1,7]}$. It is unclear whether foot examinations are important in children ${ }^{[1,7]}$. Control of hypertension in children with type 2 diabetes mellitus is mandatory ${ }^{[1,7]}$. If normotension is not achieved by ACE inhibitors, combination therapy with a-blockers, calcium antagonists or low-dose diuretics may be needed. Testing for and treating lipid abnormalities are necessary to avoid macrovascular diseases ${ }^{[1,7]}$.

\section{CHILDREN AND ADOLESCENTS WITH DIABETES MELLITUS TYPE 2: AN UN- DERSERVED POPULATION}

So far, our medical care system seems to be inadequate to care for children and adolescent with type 2 diabetes mellitus for several reasons ${ }^{[53]}$ : (1) The majority of children and adolescents with type 2 diabetes mellitus remain undiagnosed: Screening studies in obese Cau- 
casian children have reported a prevalence of $0.5 \%$ up to $1 \%$ of type 2 diabetes mellitus in obese children $\geqslant$ 12 years $^{[3]}$. Based on the prevalence of obesity of $6.5 \%$ in Central Europ ${ }^{[12,65]}$, approximately 6000 children in Germany, Austria, and Switzerland suffer from type 2 diabetes mellitus. However, in standardized prospective documentation systems of children and adolescents in Central Europe by specialized pediatric diabetes mellitus and obesity treatment centers, only nearly every sixth $(n=1071)$ child with type 2 diabetes mellitus has been registered $^{[53]}$. This high prevalence of undiagnosed type 2 diabetes mellitus has also been reported in other countries $^{[47]}$; (2) Children and adolescents with diagnosis of type 2 diabetes mellitus frequently get lost to follow-up early after diagnosis: In an European registry, 173 (80\%) of 217 children and adolescents with type 2 diabetes mellitus) were lost to follow-up after 4 mo, and only 18 children $(8 \%)$ were transferred to specialized diabetes centers $^{[53]}$. In another Central European database (the diabetes mellitus documentation system dpv), 620 (63\%) of 991 children with type 2 diabetes mellitus were lost to follow-up after $4 \mathrm{mo}^{[53]}$. These high frequencies of dropout greater than $50 \%$ have also been reported in other ethnicities with type 2 diabetes mellitus in childhood ${ }^{[66,67]}$; and (3) The recommended therapy of lifestyle intervention to achieve weight loss in type 2 diabetes mellitus is not suitable for most patients: Lifestyle intervention led to a documented reduction of overweight in only $17 \%$ of the children treated in pediatric diabetes centers ${ }^{[61]}$. Remarkably, lost to follow-up was $20 \%$ more frequent in the children treated with lifestyle interventions than in children with drug treatment ${ }^{[61]}$. Similar disappointing findings concerning weight loss were observed in most pediatric obesity treatment centers ${ }^{[68]}$.

The high drop-out rate of medical care system may be caused by the characteristics of children, and adolescents with type 2 diabetes mellitus as well as their families (e.g., lack of psychosocial support and parenting skills, lack of motivation for lifestyle changes, and inadvertent constraints to therapy adherence), but also by lacking efficacy and/or quality of medical care. Evaluation studies are urgently needed to analyze the reasons why children with type 2 diabetes mellitus are frequently lost-to follow-up.

\section{OPTIMIZING COMPLIANCE IN CHILDREN AND ADOLESCENTS WITH TYPE 2 DIA- BETES MELLITUS}

Compliance is a major problem in those with lifestylerelated diseases such as type 2 diabetes mellitus ${ }^{[60]}$. To maximize compliance and treatment adherence services for children with type 2 diabetes mellitus will need to be multidisciplinary in nature, and incorporate specific skills in pediatrics, diabetes mellitus, nutrition, psychology, social work, and diabetes mellitus education ${ }^{[60]}$. It is questionable that the traditional techniques used to optimize glycemic control in patients with type 1 diabetes mellitus are also useful in children with type 2 diabetes mellitus $^{[60]}$. Furthermore, it is debatable whether the most appropriate context for therapy of type 2 diabetes mellitus in adolescents is a tertiary pediatric hospital and yet traditionally, this is where most are referred ${ }^{[00]}$. Given the very strong family context, this is one area where an allof-family approach led by a family doctor may increase compliance since the whole family can be involved in treatment ${ }^{[60]}$.

\section{PSYCHOSOCIAL ASPECTS IN CHILDREN AND ADOLESCENTS WITH TYPE 2 DIA- BETES MELLITUS}

Adolescents with type 2 diabetes mellitus rate lower "Quality of Life" scores than their peers with type 1 diabetes mellitus ${ }^{[69]}$ and the burden of neuropsychiatric disorders in young people with type 2 diabetes mellitus is high, with as many as one in five experiencing either psychiatric illness or neurodevelopmental/behavioral problems ${ }^{[70]}$. Coupled with this, young people with type 2 diabetes mellitus are often from lower socio-economic backgrounds where social networks are less well developed to cater for the psychosocial needs of the individu$\mathrm{al}^{[60]}$. This is important as psychosocial factors represent a significant barrier to optimum self-management in adolescents with type 2 diabetes mellitus ${ }^{[71]}$, often leading to a vicious circle of spiraling poor self- management and increasing psychosocial problems ${ }^{[60]}$.

Intriguing evidence from adult studies also suggests that daily negative mood has an adverse effect on fasting glucose concentrations on the following day ${ }^{\text {[2] }}$ suggesting that poor psychosocial health may also be physiologically related to poorer glycemic control ${ }^{[60]}$. Therefore psychologists should be core component of care of children and adolescents with type 2 diabetes mellitus ${ }^{[60]}$.

\section{PREVENTION OF TYPE 2 DIABETES MEL- LITUS IN CHILDREN AND ADOLESCENTS}

The financial and societal consequences of the emerging epidemic of type 2 diabetes mellitus are substantial and demand an urgent public health response. Emphasis must be placed upon preventive behaviors and early detection. Prevention of type 2 diabetes mellitus means prevention of obesity in childhood. The effect of weight loss on comorbid conditions and, most importantly, on the development of type 2 diabetes mellitus has been unequivocally proven ${ }^{[58,73]}$. As prevention should start very early in life, perhaps even before birth, a population and community approach for prevention of obesity in childhood and hence type 2 diabetes mellitus in childhood and adolescence seems to be the most promising and reasonable treatment strategy available at present.

However, primary prevention has proven to be difficult or impossible in most societies ${ }^{[74]}$. A multidisciplinary team approach is needed to develop and secure 
preventive strategies. Good nutrition and modest exercise for pregnant women as well as monitoring of intrauterine growth of the foetus are mandatory. After birth, rapid weight gain should be avoided and the principles of good nutrition and physical activity be taught at all ages. Breast-feeding should be strongly recommended. Children's food choice can be influenced by early intervention and guidance. In fact, teacher training, modification of school meals and physical education are effective in reducing risk factors for obesity ${ }^{[16]}$.

The cost-effectiveness of group and mixed familybased treatments for childhood obesity has been tested and proven for motivated families ${ }^{[58]}$. Therefore, familybased, behavioural treatment for obesity is also effective in preventing type 2 diabetes mellitus and is also extremely cost-effective. However, in unmotivated families, treatment remains difficult and frustrating for the patients and his family, as well as for the multidisciplinary team caring for the obese child.

To prevent the development of type 2 diabetes mellitus and its life-shortening sequelae early detection of impaired glucose regulation may represent an appropriate strategy to prevent type 2 diabetes mellitus, as subjects with impaired glucose tolerance are at increased risk of developing this disease ${ }^{[75]}$. Recent intervention studies have convincingly demonstrated that adoption of a healthy lifestyle characterized by healthy eating, regular physical activity and subsequent modest weight loss can prevent the progression of impaired glucose tolerance to clinical diabetes mellitus ${ }^{[76]}$. However, the use metformin was not effective to prevent type 2 diabetes mellitus in obese adolescents with impaired glucose tolerance ${ }^{[77]}$. This might be attributed to the fact, that impaired glucose tolerance normalized physiologically at the end of puberty even without intervention ${ }^{[20]}$.

\section{CONCLUSION}

Type 2 diabetes mellitus is still rare in childhood and adolescence, but recent reports indicate an increasing prevalence around the world possibly due to increasing prevalence of obesity in children and adolescents. This is particularly the case in the United States but has also been reported in other countries in Asian and Europe. It is becoming increasingly clear that obese children and adolescents with clinical signs of insulin resistance (acanthosis nigricans, dyslipidemia, hypertension, PCOS) or relatives with type 2 diabetes mellitus or of particular ethnic populations (Asian, American Indian, AfricaAmericans, Hispanics) above the age of 10 years should be screened for type 2 diabetes mellitus. Prevention and treatment of type 2 diabetes mellitus should become one of the prime targets of public health intervention programs. Much more attention should be given to the prevention and development of preventive strategies early in life. Finally, and most importantly, public awareness of the increasing health burden and economic dimension of the childhood obesity epidemic is of importance. Physicians should make the public aware of both the childhood obesity epidemic and its serious consequences, not least type 2 diabetes mellitus.

\section{ACKNOWLEDGMENTS}

Parts of this review are adapted from the chapter Type 2 Diabetes mellitus in children and adolescents by Thomas Reinehr and Martin Wabitsch in Prevention of type 2 diabetes (Manfred Ganz editor, Wiley, first edition 2005)

\section{REFERENCES}

1 Arslanian S. Type 2 diabetes in children: clinical aspects and risk factors. Horm Res 2002; 57 Suppl 1: 19-28 [PMID: 11979018 DOI: $10.1159 / 000053308]$

2 Rodriguez BL, Fujimoto WY, Mayer-Davis EJ, Imperatore G, Williams DE, Bell RA, Wadwa RP, Palla SL, Liu LL, Kershnar A, Daniels SR, Linder B. Prevalence of cardiovascular disease risk factors in U.S. children and adolescents with diabetes: the SEARCH for diabetes in youth study. Diabetes Care 2006; 29: 1891-1896 [PMID: 16873798 DOI: 10.2337/ dc06-0310]

3 Reinehr T. Clinical presentation of type 2 diabetes mellitus in children and adolescents. Int J Obes (Lond) 2005; 29 Suppl 2: S105-S110 [PMID: 16385761 DOI: 10.1038/sj.ijo.0803065]

4 Awa WL, Boehm BO, Rosinger S, Achenbach P, Ziegler AG, Krause S, Meissner T, Wiegand S, Reinehr T, Kapellen T, Karges B, Eiermann T, Schober E, Holl RW. HLA-typing, clinical, and immunological characterization of youth with type 2 diabetes mellitus phenotype from the German/Austrian DPV database. Pediatr Diabetes 2013; 14: 562-574 [PMID: 23627341 DOI: 10.1111/pedi.12043]

5 Schober E, Waldhoer T, Rami B, Hofer S. Incidence and time trend of type 1 and type 2 diabetes in Austrian children 1999-2007. J Pediatr 2009; 155: 190-193.e1 [PMID: 19476954 DOI: $10.1016 /$ j.jpeds.2009.03.010]

6 Drake AJ, Smith A, Betts PR, Crowne EC, Shield JP. Type 2 diabetes in obese white children. Arch Dis Child 2002; 86: 207-208 [PMID: 11861246 DOI: 10.1136/adc.86.3.207]

7 Type 2 diabetes in children and adolescents. American Diabetes Association. Diabetes Care 2000; 23: 381-389 [PMID:10868870 DOI: 10.2337/diacare.23.3.381]

8 Schober E, Holl RW, Grabert M, Thon A, Rami B, Kapellen $\mathrm{T}$, Seewi $\mathrm{O}$, Reinehr T. Diabetes mellitus type 2 in childhood and adolescence in Germany and parts of Austria. Eur J Pediatr 2005; 164: 705-707 [PMID: 16012857 DOI: 10.1007/ s00431-005-1709-9]

9 Springer SC, Silverstein J, Copeland K, Moore KR, Prazar GE, Raymer T, Shiffman RN, Thaker VV, Anderson M, Spann SJ, Flinn SK. Management of type 2 diabetes mellitus in children and adolescents. Pediatrics 2013; 131: e648-e664 [PMID: 23359584 DOI: 10.1542/peds.2012-3496]

10 Rosenbloom AL, Silverstein JH, Amemiya S, Zeitler P, Klingensmith GJ. ISPAD Clinical Practice Consensus Guidelines 2006-2007. Type 2 diabetes mellitus in the child and adolescent. Pediatr Diabetes 2008; 9: 512-526 [PMID: 18694453 DOI: 10.1111/j.1399-5448.2008.00429.x]

11 Arslanian SA. Type 2 diabetes mellitus in children: pathophysiology and risk factors. J Pediatr Endocrinol Metab 2000; 13 Suppl 6: 1385-1394 [PMID: 11202214]

12 Lobstein T, Frelut ML. Prevalence of overweight among children in Europe. Obes Rev 2003; 4: 195-200 [PMID: 14649370 DOI: 10.1046/j.1467-789X.2003.00116.x]

13 Han JC, Lawlor DA, Kimm SY. Childhood obesity. Lancet 2010; 375: 1737-1748 [PMID: 20451244 DOI: 10.1016/ S0140-6736(10)60171-7]

14 Moss A, Klenk J, Simon K, Thaiss H, Reinehr T, Wabitsch $\mathrm{M}$. Declining prevalence rates for overweight and obesity 
in German children starting school. Eur J Pediatr 2012; 171: 289-299 [PMID: 21750902 DOI: 10.1007/s00431-011-1531-5]

15 May AL, Kuklina EV, Yoon PW. Prevalence of cardiovascular disease risk factors among US adolescents, 1999-2008. Pediatrics 2012; 129: 1035-1041 [PMID: 22614778 DOI: 10.1542/ peds.2011-1082]

16 Kiess W, Böttner A, Raile K, Kapellen T, Müller G, Galler A, Paschke R, Wabitsch M. Type 2 diabetes mellitus in children and adolescents: a review from a European perspective. Horm Res 2003; 59 Suppl 1: 77-84 [PMID: 12566725 DOI: 10.1159/000067829]

17 Florez JC. Clinical review: the genetics of type 2 diabetes: a realistic appraisal in 2008. J Clin Endocrinol Metab 2008; 93: 4633-4642 [PMID: 18782870 DOI: 10.1210/jc.2008-1345]

18 American Diabetes Association. Diagnosis and classification of diabetes mellitus. Diabetes Care 2013; 36 Suppl 1: S67-S74 [PMID: 23264425 DOI: 10.2337/dc13-S067]

19 Kleber M, Lass N, Papcke S, Wabitsch M, Reinehr T. Oneyear follow-up of untreated obese white children and adolescents with impaired glucose tolerance: high conversion rate to normal glucose tolerance. Diabet Med 2010; 27: 516-521 [PMID: 20536946 DOI: 10.1111/j.1464-5491.2010.02991.x]

20 Kleber M, deSousa G, Papcke S, Wabitsch M, Reinehr T. Impaired glucose tolerance in obese white children and adolescents: three to five year follow-up in untreated patients. Exp Clin Endocrinol Diabetes 2011; 119: 172-176 [PMID: 20827664]

21 Pinhas-Hamiel O, Lerner-Geva L, Copperman NM, Jacobson MS. Lipid and insulin levels in obese children: changes with age and puberty. Obesity (Silver Spring) 2007; 15: 2825-2831 [PMID: 18070774 DOI: 10.1038/oby.2007.335]

22 Weiss R, Dziura J, Burgert TS, Tamborlane WV, Taksali SE, Yeckel CW, Allen K, Lopes M, Savoye M, Morrison J, Sherwin RS, Caprio S. Obesity and the metabolic syndrome in children and adolescents. N Engl J Med 2004; 350: 2362-2374 [PMID: 15175438 DOI: 10.1056/NEJMoa031049]

23 Taksali SE, Caprio S, Dziura J, Dufour S, Calí AM, Goodman TR, Papademetris X, Burgert TS, Pierpont BM, Savoye M, Shaw M, Seyal AA, Weiss R. High visceral and low abdominal subcutaneous fat stores in the obese adolescent: a determinant of an adverse metabolic phenotype. Diabetes 2008; 57: 367-371 [PMID: 17977954 DOI: 10.2337/db07-0932]

24 Roth CL, Reinehr T. Roles of gastrointestinal and adipose tissue peptides in childhood obesity and changes after weight loss due to lifestyle intervention. Arch Pediatr Adolesc Med 2010; 164: 131-138 [PMID: 20124141 DOI: 10.1001/archpediatrics.2009.265]

25 Uwaifo GI, Fallon EM, Chin J, Elberg J, Parikh SJ, Yanovski JA. Indices of insulin action, disposal, and secretion derived from fasting samples and clamps in normal glucose-tolerant black and white children. Diabetes Care 2002; 25: 2081-2087 [PMID: 12401760 DOI: 10.2337/diacare.25.11.2081]

26 Hagman E, Reinehr T, Kowalski J, Ekbom A, Marcus C, Holl RW. Impaired fasting glucose prevalence in two nationwide cohorts of obese children and adolescents. Int J Obes (Lond) 2013; Epub ahead of print [PMID: 23828099]

27 Dabelea D, Bell RA, D'Agostino RB, Imperatore G, Johansen JM, Linder B, Liu LL, Loots B, Marcovina S, MayerDavis EJ, Pettitt DJ, Waitzfelder B. Incidence of diabetes in youth in the United States. JAMA 2007; 297: 2716-2724 [PMID: 17595272 DOI: 10.1001/jama.297.24.2716]

28 Liese AD, D'Agostino RB, Hamman RF, Kilgo PD, Lawrence JM, Liu LL, Loots B, Linder B, Marcovina S, Rodriguez $\mathrm{B}$, Standiford D, Williams DE. The burden of diabetes mellitus among US youth: prevalence estimates from the SEARCH for Diabetes in Youth Study. Pediatrics 2006; 118: 1510-1518 [PMID: 17015542 DOI: 10.1542/peds.2006-0690]

29 Rotteveel J, Belksma EJ, Renders CM, Hirasing RA, Delemarre-Van de Waal HA. Type 2 diabetes in children in the Netherlands: the need for diagnostic protocols. Eur J Endocrinol 2007; 157: 175-180 [PMID: 17656595 DOI: 10.1530/

\section{EJE-06-0754]}

30 Fagot-Campagna A, Pettitt DJ, Engelgau MM, Burrows NR, Geiss LS, Valdez R, Beckles GL, Saaddine J, Gregg EW, Williamson DF, Narayan KM. Type 2 diabetes among North American children and adolescents: an epidemiologic review and a public health perspective. J Pediatr 2000; 136: 664-672 [PMID: 10802501 DOI: 10.1067/mpd.2000.105141]

31 Sinha R, Fisch G, Teague B, Tamborlane WV, Banyas B, Allen K, Savoye M, Rieger V, Taksali S, Barbetta G, Sherwin RS, Caprio S. Prevalence of impaired glucose tolerance among children and adolescents with marked obesity. $N$ Engl J Med 2002; 346: 802-810 [PMID: 11893791 DOI: 10.1056/NEJMoa012578]

32 Wabitsch M, Hauner H, Hertrampf M, Muche R, Hay B, Mayer H, Kratzer W, Debatin KM, Heinze E. Type II diabetes mellitus and impaired glucose regulation in Caucasian children and adolescents with obesity living in Germany. Int J Obes Relat Metab Disord 2004; 28: 307-313 [PMID: 14724655]

33 Goran MI, Davis J, Kelly L, Shaibi G, Spruijt-Metz D, Soni SM, Weigensberg M. Low prevalence of pediatric type 2 diabetes: where's the epidemic? J Pediatr 2008; 152: 753-755 [PMID: 18492508 DOI: 10.1016/j.jpeds.2008.02.004]

34 Dabelea D. The accelerating epidemic of childhood diabetes. Lancet 2009; 373: 1999-2000 [PMID: 19481250 DOI: 10.1016/S0140-6736(09)60874-6]

35 Copeland KC, Zeitler P, Geffner M, Guandalini C, Higgins J, Hirst K, Kaufman FR, Linder B, Marcovina S, McGuigan P, Pyle L, Tamborlane W, Willi S. Characteristics of adolescents and youth with recent-onset type 2 diabetes: the TODAY cohort at baseline. J Clin Endocrinol Metab 2011; 96: 159-167 [PMID: 20962021 DOI: 10.1210/jc.2010-1642]

36 Liu LL, Lawrence JM, Davis C, Liese AD, Pettitt DJ, Pihoker C, Dabelea D, Hamman R, Waitzfelder B, Kahn HS. Prevalence of overweight and obesity in youth with diabetes in USA: the SEARCH for Diabetes in Youth study. Pediatr Diabetes 2010; 11: 4-11 [PMID: 19473302 DOI: 10.1111/ j.1399-5448.2009.00519.x]

37 Reinehr T, Schober E, Wiegand S, Thon A, Holl R. Betacell autoantibodies in children with type 2 diabetes mellitus: subgroup or misclassification? Arch Dis Child 2006; 91: 473-477 [PMID: 16449253 DOI: 10.1136/adc.2005.088229]

38 Pozzilli P, Di Mario U. Autoimmune diabetes not requiring insulin at diagnosis (latent autoimmune diabetes of the adult): definition, characterization, and potential prevention. Diabetes Care 2001; 24: 1460-1467 [PMID: 11473087 DOI: 10.2337/diacare.24.8.1460]

39 Niskanen LK, Tuomi T, Karjalainen J, Groop LC, Uusitupa MI. GAD antibodies in NIDDM. Ten-year follow-up from the diagnosis. Diabetes Care 1995; 18: 1557-1565 [PMID: 8722051 DOI: $10.2337 /$ diacare.18.12.1557]

40 Kobayashi T, Tamemoto K, Nakanishi K, Kato N, Okubo M, Kajio H, Sugimoto T, Murase T, Kosaka K. Immunogenetic and clinical characterization of slowly progressive IDDM. Diabetes Care 1993; 16: 780-788 [PMID: 8098691 DOI: 10.2337/diacare.16.5.780]

41 Carlsson A, Sundkvist G, Groop L, Tuomi T. Insulin and glucagon secretion in patients with slowly progressing autoimmune diabetes (LADA). J Clin Endocrinol Metab 2000; 85: 76-80 [PMID: 10634367 DOI: 10.1210/jc.85.1.76]

42 Knerr I, Wolf J, Reinehr T, Stachow R, Grabert M, Schober E, Rascher W, Holl RW. The , accelerator hypothesis': relationship between weight, height, body mass index and age at diagnosis in a large cohort of 9,248 German and Austrian children with type 1 diabetes mellitus. Diabetologia 2005; 48: 2501-2504 [PMID: 16283240 DOI: 10.1007/s00125-005-0033-2]

43 Wilkin TJ. The accelerator hypothesis: a unifying explanation for type-1 and type-2 diabetes. Nestle Nutr Workshop Ser Clin Perform Programme 2006; 11: 139-150; discussion 150-153 [PMID: 16820737 DOI: 10.1159/000094447]

44 Schober E, Rami B, Grabert M, Thon A, Kapellen T, Reinehr T, 
Holl RW. Phenotypical aspects of maturity-onset diabetes of the young (MODY diabetes) in comparison with Type 2 diabetes mellitus (T2DM) in children and adolescents: experience from a large multicentre database. Diabet Med 2009; 26: 466-473 [PMID: 19646184 DOI: 10.1111/j.1464-5491.2009.02720.x]

45 Kapadia CR. Are the ADA hemoglobin A(1c) criteria relevant for the diagnosis of type 2 diabetes in youth? Curr Diab Rep 2013; 13: 51-55 [PMID: 23109000 DOI: 10.1007/s11892012-0343-y]

46 Reinehr T, Andler W, Kapellen T, Kiess W, Richter-Unruh A, Schönau E, Seewi O, Heinze E, Wabitsch M. Clinical characteristics of type 2 diabetes mellitus in overweight European caucasian adolescents. Exp Clin Endocrinol Diabetes 2005; 113: 167-170 [PMID: 15789276 DOI: 10.1055/s-2005-837522]

47 Lobstein T, Leach R. Diabetes may be undetected in many children in the UK. BMJ 2004; 328: 1261-1262 [PMID: 15155518 DOI: $10.1136 /$ bmj.328.7450.1261-c]

48 Libman IM, Barinas-Mitchell E, Bartucci A, Robertson R, Arslanian S. Reproducibility of the oral glucose tolerance test in overweight children. J Clin Endocrinol Metab 2008; 93: 4231-4237 [PMID: 18713820 DOI: 10.1210/jc.2008-0801]

49 Reinehr T, Wabitsch M, Kleber M, de Sousa G, Denzer C, Toschke AM. Parental diabetes, pubertal stage, and extreme obesity are the main risk factors for prediabetes in children and adolescents: a simple risk score to identify children at risk for prediabetes. Pediatr Diabetes 2009; 10: 395-400 [PMID: 19140901 DOI: 10.1111/j.1399-5448.2008.00492.x]

50 Stratton IM, Adler AI, Neil HA, Matthews DR, Manley SE, Cull CA, Hadden D, Turner RC, Holman RR. Association of glycaemia with macrovascular and microvascular complications of type 2 diabetes (UKPDS 35): prospective observational study. BMJ 2000; 321: 405-412 [PMID: 10938048 DOI: 10.1136/bmj.321.7258.405]

51 Hillier TA, Pedula KL. Complications in young adults with early-onset type 2 diabetes: losing the relative protection of youth. Diabetes Care 2003; 26: 2999-3005 [PMID: 14578230 DOI: $10.2337 /$ diacare.26.11.2999]

52 Eppens MC, Craig ME, Cusumano J, Hing S, Chan AK, Howard NJ, Silink M, Donaghue KC. Prevalence of diabetes complications in adolescents with type 2 compared with type 1 diabetes. Diabetes Care 2006; 29: 1300-1306 [PMID: 16732012 DOI: $10.2337 / \mathrm{dc} 05-2470]$

53 Reinehr T, Kiess W, Kapellen T, Wiegand S, Holl RW. Children with diabetes mellitus type 2 in Europe: an underserved population. Arch Dis Child 2010; 95: 954 [PMID: 20861402 DOI: 10.1136/adc.2010.187898]

54 Shah AS, Dolan LM, Kimball TR, Gao Z, Khoury PR, Daniels SR, Urbina EM. Influence of duration of diabetes, glycemic control, and traditional cardiovascular risk factors on early atherosclerotic vascular changes in adolescents and young adults with type 2 diabetes mellitus. J Clin Endocrinol Metab 2009; 94: 3740-3745 [PMID: 19723759 DOI: 10.1210/ jc.2008-2039]

55 Hurwitz Eller N, Netterstrøm B. The intima media thickness and coronary risk factors. Int Angiol 2001; 20: 118-125 [PMID: 11533518]

56 Owada M, Hanaoka Y, Tanimoto Y, Kitagawa T. Descriptive epidemiology of non-insulin dependent diabetes mellitus detected by urine glucose screening in school children in Japan. Acta Paediatr Jpn 1990; 32: 716-724 [PMID: 2082675 DOI: 10.1111/j.1442-200X.1990.tb00910.x]

57 Fagot-Campagna A, Narayan KM, Hanson RL, Imperatore G, Howard BV, Nelson RG, Pettitt DJ, Knowler WC. Plasma lipoproteins and incidence of non-insulin-dependent diabetes mellitus in Pima Indians: protective effect of HDL cholesterol in women. Atherosclerosis 1997; 128: 113-119 [PMID: 9051204 DOI: 10.1016/S0021-9150(96)05978-3]

58 Reinehr T. Lifestyle intervention in childhood obesity: changes and challenges. Nat Rev Endocrinol 2013; 9: 607-614 [PMID: 23897171 DOI: 10.1038/nrendo.2013.149]
59 Reinehr T, Kiess W, Kapellen T, Andler W. Insulin sensitivity among obese children and adolescents, according to degree of weight loss. Pediatrics 2004; 114: 1569-1573 [PMID: 15574616 DOI: $10.1542 /$ peds.2003-0649-F]

60 Sabin M. Type 2 diabetes in children. Clinical Obesity 2013; 3: 112-116 [DOI: 10.1111/cob.12020]

61 Reinehr T, Schober E, Roth CL, Wiegand S, Holl R. Type 2 diabetes in children and adolescents in a 2-year follow-up: insufficient adherence to diabetes centers. Horm Res 2008; 69: 107-113 [PMID: 18059091 DOI: 10.1159/000111814]

62 Jones KL, Arslanian S, Peterokova VA, Park JS, Tomlinson MJ. Effect of metformin in pediatric patients with type 2 diabetes: a randomized controlled trial. Diabetes Care 2002; 25: 89-94 [PMID: 11772907 DOI: 10.2337/diacare.25.1.89]

63 Zeitler P, Hirst K, Pyle L, Linder B, Copeland K, Arslanian S, Cuttler L, Nathan DM, Tollefsen S, Wilfley D, Kaufman F. A clinical trial to maintain glycemic control in youth with type 2 diabetes. N Engl J Med 2012; 366: 2247-2256 [PMID: 22540912 DOI: 10.1056/NEJMoa1109333]

64 Inge TH, Miyano G, Bean J, Helmrath M, Courcoulas A, Harmon CM, Chen MK, Wilson K, Daniels SR, Garcia VF, Brandt ML, Dolan LM. Reversal of type 2 diabetes mellitus and improvements in cardiovascular risk factors after surgical weight loss in adolescents. Pediatrics 2009; 123: 214-222 [PMID: 19117885 DOI: 10.1542/peds.2008-0522]

65 Kurth BM, Schaffrath Rosario A. [The prevalence of overweight and obese children and adolescents living in Germany. Results of the German Health Interview and Examination Survey for Children and Adolescents (KiGGS)]. Bundesgesundheitsblatt Gesundheitsforschung Gesundheitsschutz 2007; 50: 736-743 [PMID: 17514458 DOI: 10.1007/s00103-007-0235-5]

66 Grinstein G, Muzumdar R, Aponte L, Vuguin P, Saenger $\mathrm{P}$, DiMartino-Nardi J. Presentation and 5-year follow-up of type 2 diabetes mellitus in African-American and Caribbean-Hispanic adolescents. Horm Res 2003; 60: 121-126 [PMID: 12931039 DOI: $10.1159 / 000072523]$

67 Kawahara R, Amemiya T, Yoshino M, Miyamae M, Sasamoto K, Omori Y. Dropout of young non-insulin-dependent diabetics from diabetic care. Diabetes Res Clin Pract 1994; 24: 181-185 [PMID: 7988350 DOI: 10.1016/0168-8227(94)90114-7]

68 Reinehr T, Widhalm K, l'Allemand D, Wiegand S, Wabitsch M, Holl RW. Two-year follow-up in 21,784 overweight children and adolescents with lifestyle intervention. Obesity (Silver Spring) 2009; 17: 1196-1199 [PMID: 19584877]

69 Naughton MJ, Ruggiero AM, Lawrence JM, Imperatore G, Klingensmith GJ, Waitzfelder B, McKeown RE, Standiford DA, Liese AD, Loots B. Health-related quality of life of children and adolescents with type 1 or type 2 diabetes mellitus: SEARCH for Diabetes in Youth Study. Arch Pediatr Adolesc Med 2008; 162: 649-657 [PMID: 18606936 DOI: 10.1001/archpedi.162.7.649]

70 Levitt Katz LE, Swami S, Abraham M, Murphy KM, Jawad AF, McKnight-Menci H, Berkowitz R. Neuropsychiatric disorders at the presentation of type 2 diabetes mellitus in children. Pediatr Diabetes 2005; 6: 84-89 [PMID: 15963035 DOI: 10.1111/j.1399-543X.2005.00105.x]

71 Mulvaney SA, Mudasiru E, Schlundt DG, Baughman CL, Fleming M, VanderWoude A, Russell WE, Elasy TA, Rothman R. Self-management in type 2 diabetes: the adolescent perspective. Diabetes Educ 2008; 34: 674-682 [PMID: 18669809 DOI: $10.1177 / 0145721708320902]$

72 Skaff MM, Mullan JT, Almeida DM, Hoffman L, Masharani $\mathrm{U}$, Mohr D, Fisher L. Daily negative mood affects fasting glucose in type 2 diabetes. Health Psychol 2009; 28: 265-272 [PMID: 19450031 DOI: 10.1037/a0014429]

73 Reinehr T, Kleber M, Toschke AM. Lifestyle intervention in obese children is associated with a decrease of the metabolic syndrome prevalence. Atherosclerosis 2009; 207: 174-180 [PMID: 19442975 DOI: 10.1016/j.atherosclerosis.2009.03.041] 74 Campbell K, Waters E, O'Meara S, Summerbell C. Inter- 
ventions for preventing obesity in childhood. A systematic review. Obes Rev 2001; 2: 149-157 [PMID: 12120100 DOI: 10.1046/j.1467-789x.2001.00035.x]

75 Glucose tolerance and mortality: comparison of $\mathrm{WHO}$ and American Diabetes Association diagnostic criteria. The DECODE study group. European Diabetes Epidemiology Group. Diabetes Epidemiology: Collaborative analysis Of Diagnostic criteria in Europe. Lancet 1999; 354: 617-621 [PMID: 10466661 DOI: 10.1016/S0140-6736(98)12131-1]

76 Tuomilehto J, Lindström J, Eriksson JG, Valle TT, Hämäläinen H, Ilanne-Parikka P, Keinänen-Kiukaanniemi S, Laakso
M, Louheranta A, Rastas M, Salminen V, Uusitupa M. Prevention of type 2 diabetes mellitus by changes in lifestyle among subjects with impaired glucose tolerance. $N$ Engl J Med 2001; 344: 1343-1350 [PMID: 11333990 DOI: 10.1056/ NEJM200105033441801]

77 Wiegand S, l'Allemand D, Hübel H, Krude H, Bürmann M, Martus P, Grüters A, Holl RW. Metformin and placebo therapy both improve weight management and fasting insulin in obese insulin-resistant adolescents: a prospective, placebo-controlled, randomized study. Eur J Endocrinol 2010; 163: 585-592 [PMID: 20639355 DOI: 10.1530/EJE-10-0570]

P- Reviewers: Georgescu A, Lazartigues E S- Editor: Song XX L- Editor: A E- Editor: Liu XM 


\section{WS \\ 万世登 \\ Baishideng ${ }^{\circledR}$}

Published by Baishideng Publishing Group Co., Limited Flat C, 23/F., Lucky Plaza,

315-321 Lockhart Road, Wan Chai, Hong Kong, China

Fax: $+852-65557188$

Telephone: $+852-31779906$

E-mail: bpgoffice@wjgnet.com

http://www.wjgnet.com

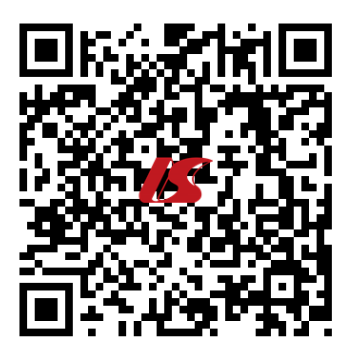

